\section{Paralytic shellfish poison algal biotoxins: Sardinia report 2002-2011 and non-compliance management}

\author{
Giuseppa Lorenzoni, ${ }^{1}$ Igor Arras, ${ }^{1}$ \\ Giovanna Sanna, ${ }^{1}$ Pietro Delogu, ${ }^{2}$ \\ Alessandro Mudadu, ${ }^{1}$ Antonio Piras, ${ }^{3}$ \\ Antonio Mura, ${ }^{2}$ Edoardo Marongiu, ${ }^{1}$ \\ Sebastiano Virgilio' ${ }^{1}$ \\ 'Istituto Zooprofilattico Sperimentale \\ della Sardegna G. Pegreffi, Sassari; \\ 2Servizio Veterinario Igiene Allevamenti e \\ Produzioni Zootecniche, ASL di Olbia, \\ Olbia; ${ }^{3}$ Servizio Veterinario Igiene \\ Alimenti, ASL di Olbia, Olbia, Italy
}

\section{Abstract}

Several microalgae of the genus Alexandrium (Alexandrium minutum and Alexandrium catenelle) can produce an algal biotoxin, the paralytic shellfish poison (PSP) that can be accumulated in the shellfish edible tissues making them hazardous to the consumer's health. In this paper we report i) the results of PSP toxins survey carried out by mouse bioassays (mouse test AOAC 958.08) on 7457 samples of bivalve molluscs farmed in Sardinia and in other European countries and marketed in Sardinia region from 2002 to 2011, and ii) the management of positive cases. Based on our experience it is very important to strictly apply the planned activities in order to prevent any risk and to protect the consumer's and producer's health.

\section{Introduction}

Human illness caused by the consumption of contaminated seafood continues to be an important problem for the shellfish industry (Milandri et al., 2008). Marine toxins, often produced as a result of harmful algal blooms (HABs), have been implicated as the causative agents of these poisonings (Kalaitzis et al., 2010). HABs are a common phenomenon in coastal countries and are caused by sudden and excessive proliferation of certain species of toxic planktonic microalgae (Anderson et al., 2002). The effects of HABs are poisoning events, resulting in the deaths of marine organisms, or the accumulation of toxins in the marine food chain can cause human poisoning. Because of the potential for shellfish poisoning via HABs, monitoring for dinoflagellates has become mandatory in most countries. Dinoflagellates are the major causative agents of HABs. It has been reported that many Dinoflagellate species can produce various toxins (Hallegraeff, 1993). These toxins can be extremely toxic at low dosage (Wang, 2008).

Paralytic shellfish poison is one of the major toxins causing health hazard to humans (Burkholder et al., 2006). PSP-producing dinoflagellate blooms have caused serious problems worldwide, such as human fatalities from eating contaminated shellfish, and economic losses due to closure of shellfish harvest (Yan et al., 2003).

Paralytic shellfish poison toxins belong to a neurotoxin group known as saxitoxins (STXs). They are mainly produced by dinoflagellates belonging to the genus Alexandrium (A. tamarensis, $A$. minutum, A.catenella, $A$. fraterculus, $A$. fundyense and $A$. cohorticula) (EFSA, 2009). STX-group toxins, cause of paralytic shellfish poisoning in humans (FAO, 2004), are a set of closely related tetrahydropurines and have been detected in filter-feeding bivalve molluscs. More than 30 different STX analogues have been identified and STX, NeoSTX, GTX1 and dc-STX are more known (EFSA, 2009).

Ingestion of PSP toxins can cause severe symptoms. In particular, it can specifically and selectively block the sodium channels on excitable cells (Deeds et al., 2008). The symptoms are purely neurological and their onset is rapid, within 30 min there is numbness of the lips and tingling, which can spread to the face and neck, and in most severe cases, there may be an altered perception to arms and legs. Respiratory difficulty is a late symptom, as a consequence of muscular paralysis and death may be the outcome within $24 \mathrm{~h}$ of consumption of the toxic shellfish (Etheridge, 2010).

There is no antidote at the moment, supportive therapy is the gastric lavage and survivor fully recover (Daranas et al., 2001). In 2002 fishermen working in harvesting sea in the Patagonia were intoxicated by consumption of filter-feeder bivalve Aulacomya ater. The two fishermen died 3-4 h after the ingestion of 7-9 ribbed mussel (Garcia et al., 2004).

According with European regulation (EC Reg. n. 853/04) (European Commission, 2004), presence of high levels of PSP toxin in bivalve molluscs (must not exceed the limit of $800 \mu \mathrm{g}$ STX eq/kg in any part edible) determines their ban on harvesting and, consequently, cannot be retailed to avoid any risk for public health. While many of the factors affecting shellfish can be actively managed, in particular those related to breeding techniques, others, affecting the occurrence of algae, are impossible to control and, consequently, difficult to predict, for example temperature and light conditions (Ade et al., 2003). A regional plan of surveillance, vigilance and sanitary control of production and marketing of molluscs, and of periodic monitoring of shellfish farming areas is in force in Sardinia. All activities are coordinated
Correspondence: Lorenzoni Giuseppa, Istituto Zooprofilattico Sperimentale della Sardegna G. Pegreffi, via Duca degli Abruzzi 8, 07100 Sassari, Italy.

Tel. +39.079 .2892348 - Fax: +39.079 .2892324$

E-mail: pina.lorenzoni@izs-sardegna.it

Key words: Shellfish, Paralytic shellfish poison algal toxins, Sardinia.

Conflict of interests: the authors declare no potential conflict of interests.

Funding: the present work was supported by the Istituto Zooprofilattico Sperimentale della Sardegna.

Conference presentation: the present paper was presented at the at the XXII AIVI Congress, 19-21 September 2012, Turin, Italy.

Received for publication: 31 January 2013. Revision received: 26 April 2013.

Accepted for publication: 26 April 2013.

This work is licensed under a Creative Commons Attribution 3.0 License (by-nc 3.0).

(C) Copyright G. Lorenzoni et al., 2013

Licensee PAGEPress, Italy

Italian Journal of Food Safety 2013; 2:e30

doi:10.4081/ijfs.2013.e30

by the Dipartimento di Prevenzione dell'Assessorato alla Sanità and implemented by Servizi Veterinari e Medici delle Aziende Sanitarie Locali (ASL), Istituto Zooprofilattico della Sardegna (IZS) and Dipartimento di Botanica ed Ecologia Vegetale, University of Sassari. The regional plan, regarding the surveillance, provides the control of potentially toxic algae, eventually present in breeding waters, also, detection and quantification of toxins, sampling almost biweekly both water and molluscs. regarding the vigilance, the main objective of the regional plan is verification of compliance with microbiological, and chemical requirements both in production and marketing (Regione Sardegna, 2011).

The objectives of our paper was to document the activities contemplate in the regional plans from 2002 to 2011 in Sardinia; to verify the respect of biotoxicological requirements for the PSP toxins indicated in the EC Reg. n. $853 / 04$, in a representative bivalve sample collected in breeding areas and retailed in Sardinia; to identify the management procedure of non compliance resulting in the presence PSP toxins in bivalve molluscs.

\section{Case Report}

During the implementation of the regional 
plans of surveillance, vigilance and sanitary control and controls on live molluscs imported from EU countries, as provided for veterinary office community obligations of Sardinia, a total amount of 7457 bivalve mollusc samples were analysed for PSP toxins presence by using the mouse bioassay (mouse test AOAC 958.08) from 2002 to 2011. In particular, 776 samples in 2002; 754 in 2003; 712 in 2004; 762 in 2005; 944 in 2006; 843 in 2008; 628 in 2009; 671 in 2010; 723 in 2011 (Virgilio et al., 2003, 2004, 2005, 2006, 2007, 2009; Lorenzoni et al., 2011) were tested. Briefly, $100 \mathrm{~g}$ of shellfish tissue sample were boiled in $100 \mathrm{~mL}$ of $0.1 \mathrm{~N}$ HCL for $5 \mathrm{~min}$, after adjustment of volume to $200 \mathrm{~mL}$ to reach the ideally $\mathrm{pH}$ to 3 , they were centrifuged at $3000 \mathrm{rpm}$ for $5 \mathrm{~min}$. The extract was injected intraperitoneally with $1 \mathrm{~mL}$ of supernatant into 3 mice, symptoms, in terms of mouse behavior after injection, were observed, and lethal time was recorded, the test was considered positive when the mice died within a specific time period; the time of death is used to quantify the level of toxin present (AOAC 959.08) (AOAC, 2005).

In Table 1, the number of mollusc samples analyzed, their positivity for PSP toxins, and their percentage are summarized; all data are related to the year. In Sardinia, PSP toxins was found in 16 samples collected in Olbia gulf out of a total of 776 samples in 2002 (Virgilio et al., 2003); 12 samples collected in Olbia gulf out of a total of 754 samples in 2003 (Virgilio et al., 2004); in 15 samples collected in Cugnana gulf (Olbia) out of 762 samples in 2005 (Virgilio et al., 2005), in 26 samples collected in Spain and destined to a farm located in Oristano (Virgilio et al., 2006) and in 5 samples of local production out of a total of 944 samples examined in 2006 (Virgilio et al., 2007); in 11 samples collected in Cugnana gulf and Porto Pozzo (Olbia) and in 5 samples gathered in Oristano gulf out of total of 834 samples in 2008 (Virgilio et al., 2009); in 14 samples collected in Cugnana and Porto Pozzo out of a total of 628 samples in 2009; in 5 collected in Porto Pozzo of a total of 671 samples analyzed in 2010; in 2 collected in of a total of 723 samples in 2011 (Lorenzoni $e t$ al., 2011). None positivity was found in the year 2004, of a total of 712 samples, and during 2007 , of a total of 653 samples. Two mollusc farming areas with a high risk level have been identified in Sardinia: one is located in Olbia gulf, Cugnana and Porto Pozzo, the other in Oristano gulf, both presented HABs caused by A. minutum and A. catenella (Figure 1).

In Table 2, as referred to Olbia gulf, Porto Pozzo and Cugnana, information about the period where the PSP toxins was found, the number of samples analyzed during that period, the number of positive samples and the origin area are shown.

In Table 3, the same parameters are shown as referred to Oristano gulf.

\section{Discussion}

In 1976 a PSP outbreak was recorded in Western Europe, after the consumption of shellfish breeded in Spain, there were reported 38 poisoning cases in Italy (Ade et al., 2003). During the year 1993, in mussels from the main breeding areas along the Emila Romagna coast, were found low levels of goniau toxin. This data showed the presence of algae able to produce PSP toxin in the Adriatic sea (Ade $e t$ al., 2003). Moreover, an outbreak connected with the PSP toxins in molluscs of local production was reported along the emiliano-romagnola coast in the 1994 in Italy (Ciminiello et al., 1995).

Tables 1, 2, 3 show PSP-toxicity events in bivalve molluscs farmed in various marine areas of Sardinia. In Sardinia all analysis for PSP toxins from 1991 to 2001 were always negative (Virgilio et al., 2001). The first event of PSP toxicity reported in Olbia's gulf in May 2002 has been associated with the presence of A. minutum and $A$. catenella. The presence of A. Catenella in the gulf of Olbia has been

Table 1. Biotoxicological determination of paralytic shellfish poison in bivalve molluscs by mouse bioassay (Sardinia, from 2002 to 2011 ).

\begin{tabular}{lccc}
\hline Analysed molluscs $(\mathrm{n})$ & \multicolumn{2}{c}{ PSP positive molluscs } & Year \\
& $\mathrm{n}$ & $\%$ & 2002 \\
776 & 16 & 2.0 & 2003 \\
754 & 12 & 1.6 & 2004 \\
\hline 712 & 0 & 0 & 2005 \\
762 & 15 & 2.0 & 2006 \\
\hline 944 & 31 & 3.3 & 2007 \\
\hline 653 & 0 & 0 & 2008 \\
\hline 834 & 16 & 1.9 & 2009 \\
\hline 628 & 14 & 2.2 & 2010 \\
\hline 771 & 5 & 0.7 & 2011 \\
723 & 2 & 1.4 & \\
\hline Total & & & $2002-2011$ \\
\hline 7457 & 111 & 1.5 & \\
\hline
\end{tabular}

PSP, paralytic shellfish poison.

Table 2. Olbia positive results of paralytic shellfish poison toxins algae analysed by mouse bioassay related to month, year and areas/origins.

\begin{tabular}{lccl} 
Month (year) & $\begin{array}{c}\text { Analysed } \\
\text { molluses (n) }\end{array}$ & $\begin{array}{c}\text { PSP positive } \\
\text { molluscs (n) }\end{array}$ & Area/origin \\
May (2002) & 74 & 16 & Olbia gulf/local \\
April, May (2003) & 181 & 12 & Olbia gulf/local \\
\hline January, February (2005) & 25 & 15 & Cugnana gulf/local \\
December (2008) & 20 & 11 & $\begin{array}{l}\text { Cugnana gulf and } \\
\text { Porto Pozzo/local }\end{array}$ \\
\hline January, February (2009) & 25 & 14 & Cugnana gulf and \\
February, March, December (2010) & 69 & 5 & Porto Pozzo/local \\
January (2011) & 7 & 2 & Porto Pozzo/local \\
\hline
\end{tabular}

PSP, paralytic shellfish poison.

Table 3. Oristano positive results of paralytic shellfish poison toxins algae analysed by mouse bioassay related to month, year and areas/origins.

\begin{tabular}{lccl} 
Month (year) & $\begin{array}{c}\text { Analysed } \\
\text { molluses (n) }\end{array}$ & $\begin{array}{c}\text { PSP positive } \\
\text { molluses (n) }\end{array}$ & Area/origin \\
January (2006) & 36 & 26 & Oristano's gulf/EU \\
November (2006) & 18 & 5 & Oristano's gulf/local \\
\hline November (2008) & 5 & 5 & Oristano's gulf/local \\
\hline
\end{tabular}

PSP, paralytic shellfish poison; EU, European Union. 
reported for the first time in 1999, with subsequent confirmation in 2000 and 2001 still in summer months (Lugliè et al., 2003a, 2003b, 2003c). This is one of the first reports of $A$. catenella in Italian waters as specie recently introduced in the Mediterranean sea. Other reports include the Balearic basin (Margalef and Estrada, 1987), Valencia harbour (Gomis et al., 1996) and Catalan coast of Spain (Vila et al., 2001). Toxic events were also reported in Thau lagoon from the Mediterranean coast of France (Masselin et al., 2001).

Genetic analysis showed that $A$. catenella form the Mediterranean is closely related to the A. catenella of Asia (Penna et al., 2003a, 2003b; Lugliè et al., 2003b). For that reason it is supposed that $A$. catenella is an alien specie introduced with ballast water discharged from foreign ships and, consequently, biological material were transferred to shellfish farmings.

In the spring 2003, in the gulf of Olbia in Sardinia, the rebound phenomena of algal blooms and accumulation of toxins in bivalve molluscs were occurred.

Frequent observations of $A$. catenella from 1999, allows supposing that, despite of possible recent introduction, this specie, through mechanisms of adaptation and survival, has represented a public health risk now steadily present in the area. Development of temporary and permanent cysts is one of main survival mechanisms through that accumulation in marine sediment makes them capable to germinate and create the new blooms in suitable environmental conditions. Previous studies clearly reported that the gulf of Olbia, among the Sardinian areas of breeding and harvesting of wild and farmed shellfish, was a problematic site. This area was characterized by increasing risk not only for the dangerous spe-

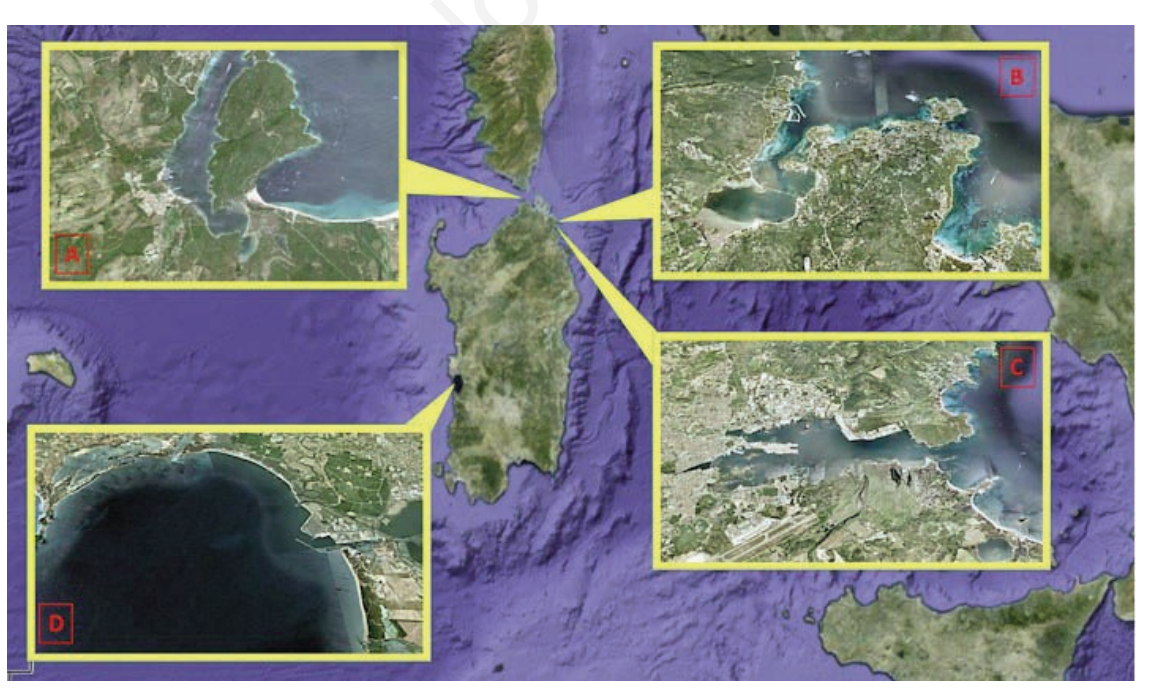

Figure 1. Map of Sardinia (Italy). A) Porto Pozzo; B) Cugnana gulf; C) Olbia gulf; D) Oristano gulf. cies observed able to develop high density during all year, but also for predisposing events, including low hydrodynamics, high trowater from ships, finally, aquaculture activities with introduction of biological material from other sites (Sannio et al., 1996, 1997).

According to data reported in literature, even in the areas where $A$. catenella constitutes an element of the autochthonous phytoplankton, the possibility of events prediction is low, both in terms of time and risks. In various species of dinoflagellates responsible for PSP, in fact, toxins combination, their potency and the extent of production can vary depending on geographical and environmental conditions. Furthermore, the amount of toxins per cell changes, it is probably due to the physiological state of populations and it decreases for decreasing of nutrients (Masó and Garcés, 2006). Toxin accumulation in various parts of shellfish is different and the contamination range is depending on species, also relative to the time in which it arises (few weeks may be enough as previously reported in Olbia's cases). For this reason, especially in the areas of breeding, very strict monitoring programs for $\mathrm{HAB}$ events and shellfish contamination are increased with frequent and unavoidable embargo at the market.

In the gulf of Cugnana (Olbia) the appearance of the algal bloom phenomena and the resulting accumulation of biotoxins in bivalve molluscs occurred in winter months of 2005 and in the autumn and winter of 2008 and 2009 (Lugliè et al., 2009). The molluscs in the area of Porto Pozzo (Olbia) have been never affected by accumulation of algal toxins until December 2008, then reappeared always in winter months of 2009, 2010 and 2011 (Lorenzoni et al., 2011)

\section{(1)} phic activity, harbor with discharge of ballast

Sar

In Oristano in January 2006, several batches of molluscs coming from an EU country were found contaminated by PSP during the sanitary checks at arrival. In November of the same year, the phenomenon also affected local production (Virgilio et al., 2007). At the end of 2008, mussels farmed in the gulf of Oristano showed to be contaminated by PSP toxins (Virgilio et al., 2009). Following these positive findings, series of measures were promptly adopted.

As for the non-compliance management in Sardinia, whenever the Official Laboratory of IZS observes algal toxins in quantities exceeding EU regulation limits, immediately notify the analysis outcome to the food safety authorities, local health Service of ASL, which carried out the sampling, ASL notify to the local authority (mayor) the immediate proposal for adoption of temporary and cautionary suspension of live bivalve molluscs harvest. ASL must also notify these measures to farms operating within the affected area for requirements it may concern, to region (Departments of Health and Environment) for the fulfillment of jurisdiction, to the other services of the Department of Prevention that may be involved. Next the ASL explore the possibility to activate the alert system (in order to identify and withdrawal and/or confiscation of concerned and suspicious items), to intensify supervision on commercial circuit, to start an intensive sampling of the contaminated shellfish and other species in breeding farms in which positivity was found in adjacent farms and natural areas bordering the classified area.

Restriction may be revoked by the territorial jurisdiction Veterinary Service of the ASL only after safety requirements are restored, which is after at least two consecutive results (within at least $48 \mathrm{~h}$ of each other) below limit values fixed by Community Regulation.

In case of detection of PSP toxins in local retail products it is immediately necessary to implement procedures for traceability and withdrawal / recall of the product and adoption of harvest suspension.

When detection of PSP toxins affect products from others EU countries, it is evident that safety guarantees taken by importing country giving out before products shipment.

When the detection of non-compliance occur at destination, the veterinary offices for compliance with community requirements (UVAC) can dispose rejection of the products and intensify checks of following batches of similar type and origin and it can activate the alert system community (RASFF), while local health authority has the assignment to order the seizure and subsequent destruction of non-conforming goods in question (Regione Sardegna, 2011). 


\section{Conclusions}

To prevent the human pathologies, our experience indicate the importance of a strict application of the activities reported in the regional plan. Despite the persistent presence of PSP toxins from 2002 to now in bivalve molluscs in Sardinia, none human intoxication related to PSP toxins was reported. In our region, the system of prevention and control was particularly effective, and all episodes of toxicity of molluscs have been duly highlighted.

\section{References}

Ade P, Funari E, Poletti R, 2003. [Il rischio sanitario associato alle tossine di alghe marine]. [Article in Italian]. Ann. Ist. Super. Sanità 39:53-68.

Anderson D, Glibert P, Burkholder J, 2002. Harmful algal blooms and eutrophication: nutrient sources, composition and consequences. Estuaries 25:704-26.

AOAC, 2005. Officinal methods of analysis. 18th ed. Association of Official Analytical Chemists ed., Gaithersburg, MD, USA.

Burkholder J, Azanza R, Sako Y, 2006. The ecology of harmful dinoflagellates. In: Graneli E, Turner J, eds. Ecology of harmful algae. Springer, Heidelberg, pp 53-66.

Ciminiello P, Fattorusso E, Magno S, 1995. Determination of PSP toxins in mussels of the northern Adriatic Sea. Mar Pollut Bull 11:733-5.

Daranas AH, Norte M, Fernandez JJ, 2001. Toxic marine microalgae. Toxicon 39:1101-13.

Deeds JR, Landsberg JH, Etheridge SM, Pitcher GC, 2008. Non-traditional vectors for paralytic shellfish poisoning. Mar Drugs 6:308-48.

EFSA, 2009. Marine biotoxins in shellfish-saxitoxin grup. The EFSA Journal 1019:1-76.

Etheridge SM, 2010. Paralytic shellfish poisoning: seafood safety and human health perspectives. Toxicon 56:108-22.

European Commission, 2004. Regulation of the European Parliament and of the Council of 29 April 2004 laying down specific hygiene rules for food of animal origin, 853/2004/EC. In: Official Journal, OJ L 139, $30 / 04 / 2004$.

FA0, 2004. Marine biotoxins. Food and Agriculture Organization of the United Nations ed., Rome, Italy. Available from: http://www.fao.org/docrep/007/y5486e/y548 6e00.HTM

Garcia C, del Carmen Bravo M, Lagos M, Lagos N, 2004. Paralytic shellfish poisoning: post-mortem analysis of tissue and body fluid samples from human victims in the Patagonia fjords. Toxicon 43:149-58.

Gomis C, Alcober J, Bernabeu A, 1996. [Seguimiento de las poblaciones fitoplancton icasen las bateas mejilloneras del puerto de Valencia, 1991-1994]. In: Matamoros E, Delgado M, eds. [IV Reunion Ibérica de Fitoplancton Toxico y Biotoxinas. Generalitat de Catalunya]. [Proceedings in Spanish]. Department of Agriculture, Animal husbandry and Fishery, St. Carles de la Ràpita, Spain, pp 29-38.

Hallegraeff GM, 1993. A review of harmful algal blooms and their apparent global increase Phycologica 32:79-99.

Kalaitzis JA, Chau R, Kohli GS, 2010. Biosynthesis of toxic naturally-occurring seafood contaminants. Toxicon 56:244-58.

Lorenzoni G, Arras I, Sanna G, 2011. Presence of toxins algal type P.S.P in mussels and non-compliance management. In: Proceedings of the XIII National Congress S.I.Di.L.V., Trani, 12-14 October.

Lugliè A, Buzzoni AM, Satta CT, 2009. Events of paralytic shellfish poisoning (PSP) in shellfish areas along the Sardinia'coasts. In: XIX Congress of the Italian Association of Oceanology and Limnology, Venezia, S. Servolo island, 23-25 September.

Lugliè A, Giacobbe MG, Fiocca F, 2003a. The geographical distribution of Alexandrium catenella is extending to Italy! First evidences from the Tyrrhenian Sea. In: Steidinger A, Landsberg JH, Tomas CR, eds. Harmuful algae 2002. Proceedings of the X International Conferente on Harmful Algae. Florida Fish and Wildlife Conservation Commission and Intergovernmental Oceanographic Commission of UNESCO ed., St. Pete Beach, FL, USA.

Lugliè A, Giacobbe MG, Penna A, 2003b. [Conoscenza e gestione della fascia marina costiera. Presenza e significato di specie di Alexandrium in aree portuali della Sardegna]. In: [ $98^{\circ}$ Congresso della Società Botanica Italiana]. [Proceedings in Italian]. University of Catania, 24-26 September.

Lugliè A, Giacobbe MG, Sannio A, Fiocca F, Sechi N, 2003c. First record of the dinoflagellate Alexandrium catenella (Dinophyta), a potential producer or paralytic shell fish poisoning, in Italian waters (Sardinia, Tyrrhcnian Sea). Bocconea 16:1045-51.

Margalef R, Estrada M, 1987. Synoptic distribution of summer microplankton (Algae and Protozoa) across the principal front in the Western Mediterranean. Invest Pesq 51:121-40.

Masó M, Garcés E, 2006. Harmful microalgae blooms (HAB); problematic and conditions that induce them. Mar Pollut Bull 53:62030.

Masselin P, Amzil Z, Abadie E, 2001. Paralytic shellfish poisoning on the French Mediterranean coast in autumn 1998: Alexandrium "tamarense complex" (Dinophyceae) as causative agent. In: Hallegraelf GM, Blackburn SL, Bolch CL, eds. Hannful algal blooms 2000. Proceedings of the 9th International Conference on Hannful algal blooms, Paris, pp 22-29.

Milandri A, Cangini M, Costa A, 2008. Characterization of P.S.P toxins (Paralytic Shellfish Poisoning) in mussels collected in different Italian marine areas. In: Proceedings of the 39th Congress of Marine Biology of the Italian Society of Cesenatico (FC), 9-13 June, pp 38-41.

Penna A, Magnani M, Bertozzini E, 2003a. Biogeographic distribution of the Alexandrium species in the western Mediterranean Sea: preliminary results by genetic analyses. In: Proceedings of the 3rd European Phycological Congress, Belfast, July, pp 21-26.

Penna A, Magnani M, Bertozzini E, 2003b. Population diversity of Alexandrium species in the Western Mediterranen Sea: preliminary results by genetic analysis. In: Proceedings of the EUROHAB cluster workshop, Amsterdam, 17-18 March, pp 50-51.

Regione Sardegna, 2011. [Piano regionale per la vigilanza ed il controllo sanitario della produzione e commercializzazione dei molluschi bivalvi vivi e per il monitoraggio periodico delle zone di produzione e di stabulazione di molluschi bivalvi vivi, anno 2011. Regulation n. 0004212/Det/111]. [Regulation in Italian]. Regione Sardegna ed., Sassari, Italy.

Sannio A, Lugliè A, Sechi N, 1996. The phytoplankton of the internal Gulf of Olbia (North-East Sardinia) between July 1992 and July 1993. Giorn. Bot. Ital. 130:103750.

Sannio A, Sechi N, Luglié A, 1997. Potentially toxic dinoflagellates in Sardinia. Plant Biosyst 131:73-8.

Vila M, Garcés E, Masó M, Camp J, 2001. Is the distribution of the toxic dinoflagellate Alexandrium catenella expanding along the NW Mediterranean coast. Mar EcolProg Ser 222:73-83.

Virgilio S, Lorenzoni G, Marongiu E, 2009. Presence of P.S.P. (Paralitic Shellfish Poison) in mussels of Sardinia and nonconformity management. In: Proceedings of the XIX National Congress A.I.V.I., Perugia, 24-26 June.

Virgilio S, Marongiu E, Lorenzoni G, 2005. Determination of paralytic shellfish poison toxins in mussels and edible sea urchin paracentrotus lividus. In: 
Proceedings of the XV National Congress A.I.V.I., Tirrenia (PI), 16-18 June, pp 299304.

Virgilio S, Marongiu E, Lorenzoni G, 2007. Sanitary risks by contamination P.S.P. toxins (Paralytic Schellfish Poison) in mussels and emergency management in Sardinia. In: Proceedings of the XVII National Congress A.I.V.I., Cesenatico, 1416 June.

Virgilio S, Marongiu E, Mancuso R, 2001. [Biotossine algali e molluschi bivalvi vivi. I controlli sanitari nella regione Sardegna]. [Proceedings in Italian]. In: Proceedings of the XI National Congress
A.I.V.I., Alghero, 5-7 September.

Virgilio S, Marongiu E, Pisanu M, 2003. Presence and determination of P.S.P (Paralytic Shellfish Poisoning) toxins in mussels of Olbia, Sardinia. In: Proceedings of the XIII National Congress A.I.V.I., Montesilvano (Pescara), 6-8 June, pp 209-213.

Virgilio S, Marongiu E, Piras A, 2004. The evolution of contamination by P.S.P. toxins (Paralytic Shellfish Poison) in Olbia gulf mussels, Sardinia. In: Proceedings of the XIV National Congress A.I.V.I., Santuario di Vicoforte (CN), 4-6 June, p 43-49.

Virgilio S, Pisanu M, Lorenzoni G, 2006.
Sanitary risk by Paralytic Schellfish Poison toxins in mussels subject to international trade. In: Proceedings of the XVI National Congress A.I.V.I., Bari, 22-24 June, pp 262 7.

Wang D, 2008. Neurotoxins from marine dinoflagellates: a brief review. Mar Drugs 6:349-71.

Yan T, Zhou M, Tan Z, 2003. A survey for paralytic shellfish poisoning (PSP) in Vancouver Harbour. Mar Environ Res 57:137-43. 